\title{
PENYEBARAN KONSENTRASI POLUTAN DENGAN PEMODELAN DISPERSI GAUSS MENGGUNAKAN MATLAB
}

\author{
*Jainal Abidin, Ferawati Artauli Hasibuan \\ Program Studi Pendidikan Fisika, Universitas Graha Nusantara Padangsidimpuan \\ *Email: abidinjainal27@gmail.com
}

DOI: http://dx.doi.org/10.29303/jpft.v5i2.1341

\begin{abstract}
$\overline{\text { Abstract } \text { - In the era of development of science and technology until } 2019 \text { it has become increasingly }}$ sophisticated and makes life easier for humans. This progress has led to increasingly sophisticated technology with the intention of making life easier, practical, efficient and not experiencing much difficulty. But the development of these technologies, have positive and negative impacts. Positive impacts such as convenience, while negative impacts such as air pollution. Contamination of pollutants into the air resulting from factory activities, power plants and motor vehicles spread to the environment. This substance is very damaging to the environment which causes the air we breathe to be polluted and very influential on health. This study aims to describe the process of spreading pollutant concentrations in the air originating from factory chimney fumes. Pollutants that spread in the air can be modeled with the dispersion gauss model which is processed using the MATLAB programming language. The expected results from modeling are the distance of the highest pollutant concentration area and the range of pollutant coverage that spread, so that later will be done variations of the effective height of the chimney emission $(H)$ to get results that vary according to the height of the chimney.
\end{abstract}

Keywords: Air Pollution, Pollutant Concentration, Gauss Dispersion Model

\section{PENDAHULUAN}

Pada masa teknologi dan ilmu pengetahuan hingga tahun 2019 ini telah semakin canggih dan semakin mempermudah hidup manusia. Seiring dengan kemajuan tersebut menyebabkan kebutuhan manusia terus meningkat sehingga membutuhkan kemajuan manusia dalam berfikir. Dengan berpikir manusia menciptakan teknologi dengan maksud agar hidup lebih mudah, praktis, efisien dan tidak banyak mengalami kesulitan. Secara umum, perkembangan teknologi merupakan peralatan yang terus mengalami perubahan dari tahun ke tahun, baik dalam bentuk fisik maupun segi proses pelaksanaannya.

Teknologi membuat dunia ini berubah. Dengan semakin majunya teknologi menyebabkan dampak bagi manusia. Dampak ini terdiri dari 2 yaitu dampak positif dan dampak negatif. Dampak positifnya sangat banyak membantu kegiatan manusia contohnya pada bidang informasi yang bisa dilakukan secara cepat dalam pengiriman data/informasi.
Disamping ada banyak dampak positif yang didapatkan dari perkembangan teknologi tidak terlepas dari dampak negatif. Contohnya pencemaran lingkungan akibat polusi udara, penggunaan zat kimia, pemanasan global dan sangat merugikan manusia. Dampak buruk bagi kesehatan akibat polusi udara telah dievaluasi dalam banyak penelitian, terutama difokuskan pada negara-negara maju dan daerah perkotaan (Xi et al. 2019).

Pada penelitian ini bertujuan untuk memberikan gambaran dan pengetahuan terhadap masyarakat awam tentang penyebaran konsentrasi polutan di udara. Sangat penting pengetahuan tentang penyebaran dari konsentrasi polutan bagi masyarakat awam. Masyarakat awam banyak yang belum paham tentang polusi udara, baik itu proses sebarannya maupun efek yang dihasilkan serta bagaimana untuk mengatasinya. Sehingga diperlukan suatu simulasi untuk menjelaskan proses terjadinya penyebaran polutan yang nantinya diharapkan menambah 
pengetahuan masyarakat tentang daerahdaerah yang memiliki efek yang paling banyak konsentrasi polutannya, sejauh mana sebaran itu menyebar, serta bagaimana mengatasi atau mengurangi efek dari polusi udara. Untuk itu, penelitian ini akan membahas tentang pemodelan penyebaran konsentrasi polutan yang terjadi di udara. Udara adalah salah satu sumber kehidupan bagi keberlangsungan hidup makhluk hidup. Sehingga untuk bernapas diperlukan udara yang bersih tanpa terkontaminasi oleh zatzat polutan.

Polusi udara yang dihasilkan dari aktivitas industri/pabrik, pembangkit listrik, kebakaran hutan dan kenderaan bermotor menyebar ke lingkungan sehingga lingkungan terkontaminasi zat dari polutan tersebut. Zat ini sangat merusak ekosistem lingkungan mengakibatkan udara yang kita hirup sangat berpengaruh pada kesehatan dan juga memicu proses pemanasan global. Pada pemodelan ini, ada beberapa metode maupun model yang dapat digunakan untuk menggambarkan proses penyebaran konsentrasi polutan. Diantaranya ada Metode Vector Autoregressive (VAR), Model Estimasi Dispersi Atmosferis, Pemodelan Lintasan dan Data Pemantauan, Model Alat Respons Cepat Berbasis Pembelajaran Mesin, serta Model Dispersi Gauss. Dalam penelitian ini model yang akan digunakan adalah model dispersi Gauss. Model dispersi Gauss adalah salah satu model matematika yang paling terkenal yang dapat memprediksi konsentrasi polutan dari sumber titik yang terus-menerus (Apiratikul, 2015). Evaluasi dan kalibrasi model dispersi dari sangat penting, karena hasil mereka sering mempengaruhi keputusan yang memiliki besar kesehatan masyarakat dan konsekuensi ekonomi (Brusca, et al 2016). Persamaan matematika yang digunakan dapat diselesaikan dengan melakukan dengan program komputasi untuk mensimulasikan dispersi polutan
(Varma et al. 2014). Untuk itu, dalam penggunaan formula matematika berdasarkan simulasi dengan model dispersi Gauss akan didapatkan gambaran dari sebaran konsentrasi polutan di udara.

\section{A. Perkembangan Ilmu}

IPTEK adalah singkatan dari ilmu pengetahuan dan teknologi. Dari zaman kuno sampai pada zaman modern saat ini sudah banyak terjadi perubahan yang diakibatkan oleh perkembangan IPTEK. Ilmu pengetahuan muncul sebagai akibat dari aktivitas untuk memenuhi kebutuhan hidup manusia, baik kebutuhan jasmani maupun kebutuhan rohani. Dengan perkembangan IPTEK yang sangat pesat, patut merasa beruntung karena kita akan sangat termajakan dengan berbagai fasilitas berteknologi modern yang murah dan praktis, dan itu juga yang pada akhirnya membuat kita khawatir. Disamping kemudahan yang didapatkan dari perkembangan IPTEK memiliki dampak yang tidak baik pada kehidupan. Contohnya seperti polusi udara yang dihasilkan dari gas buang pabrik dan kenderaan bermotor. Dengan tercemarnya udara disekitar sangat mengganggu kesehatan dan polusi udara salah satu pemicu terjadinya pemanasan global. Hal ini perlu dikhawatirkan, dengan menghirup udara yang telah terkontaminasi oleh zat polutan dari asap pabrik dan kenderaan bermotor akan menyebabkan timbulnya penyakit dan merusak lingkungan. Seterusnya akibat penipisan lapisan ozon yang diakibatkan dari pemanasan global akan mengakibatkan kanker kulit akibat radiasi sinar matahari yang tidak terlindungi oleh lapisan ozon.

Dampak perkembangan juga mengakibatkan orang-orang semakin malas karena kemudahan-kemudahan yang ditawarkan oleh teknologi. Pembodohan akan terjadi jika terlena akan kemudahan yang ditawarkan oleh teknologi. Untuk itu, perlu difilter dan diimbangi kemajuan 
teknologi tersebut. Jika perkembangan teknologi disamping memberikan kemudahan juga mengakibatkan kerusakan maka perlu berpikir kreatif untuk mengimbanginya. Contohnya dengan melakukan penghijauan kembali hutan.

\section{B. Polutan Sebagai Pencemar Udara}

Udara adalah salah satu sumber kehidupan untuk makhluk hidup. Manasia memerlukan udara yang bersih untuk pernapasan. Udara merupakan campuran beberapa gas yang perbandingannya tidak tetap, tergamtung pada keadaan suhu udara, tekanan udara dan keadaan lingkungan sekitar. Udara bersih adalah udara yang tidak tampak, tidak berbau, tidak berwarna dan berasa. Pencemaran udara adalah salah satu masalah utama dalam ilmu lingkungan yang perlu evaluasi dampak terhadap lingkungan dari proyek-proyek yang dilakukan untuk mencegah dampak buruk terhadapat lingkungan (Apiratikul, 2015). Berdasarkan Undang-Undang Pokok Pengolahan Lingkungan Hidup No. 4 Tahun 1982, pencemaran lingkungan atau polusi adalah masuknya atau dimasukkannya makhluk hidup, zat energi, dan atau komponen lain ke dalam lingkungan, atau berubahnya tatanan lingkungan oleh kegiatan manusia atau oleh proses alam sehingga kualitas lingkungan menjadi kurang atau tidak dapat berfungsi lagi sesuai peruntukkannya. Adanya zat pencemar di udara ambiem berasal dari sumber emisi gas buang, baik alami maupun sumber emisi buatan manusia atau aktivitas kegiatan manusia (Patmasari, 2018). Pencemaran udara merupakan proses masuknya polutan ke dalam lingkungan sehingga dapat menurunkan kualitas udara di lingkungan tersebut.

Pencemaran udara seringkali tidak dapat ditangkap oleh panca indera kita, walaupun demikian potensi bahayanya tetap ada. Jika panca indera kita dapat menangkap maka tentunya bentuk pencemaran udara yang terjadi justru merupakan hal yang sangat mengerikan atau sudah sangat parah. Sebagai contoh mata kita dapat melihat gas buangan hasil pembakaran berbentuk asap tebal hitam, berarti komponen partikel di dalam asap tersebut sangat banyak. Jika saja hidung kita dapat mencium bau pencemar udara atau bahkan merasa sesak pada dada akibat mencium gas tersebut, maka hal ini berarti tingkat pencemaran udara sudah tinggi dan mungkin saja akan menjadi racun yang dapat mematikan.

Polutan adalah suatu zat atau bahan yang menyebabkan terjadinya polusi, di mana keberadaannya di suatu lingkungan dapat menyebabkan kerugian terhadap makhluk hidup (Patmasari, 2018). Zat pencemar udara dapat dibedakan atas partikular (aerosol) dan zat pencemar dalam bentuk gas. Dalam prosesnya zat pencemar dalam bentuk gas atau partikular dapat tersusun dari senyawa anorganik dan organik. Bebarapa zat yang terdapat pada polutan yang mengakibatkan terjadinya pencemaran udara, diantaranya: Karbon monoksida, Karbondioksida, Nitrogen dioksida, Sulfur dioksida, Partikular, Hidrokarbon, CFC, dan Timbal.

\section{Dispersi Gauss}

Dispersi merupakan proses terjadinya aliran polutan yang kontinu terlepas dari sumbernya (cerobong) dan tertiup oleh angin tetap (stady state) di atmosfer terbuka, aliran polutan tersebut akan berbelok ke bawah dan terus bergerak sesuai dengan arah rata-rata angin yang menyebarkan konsentrasi polutan dan membawanya menjauhi sumbernya (Patmasari, 2018). Dispersi Gauss adalah model perhitungan melalui persamaan dan algoritma untuk menjelaskan dengan cara yang disederhanakan fenomena dari dispersi polutan di atmosfer (Iodice \& Senatore, 2015). Input dari model dispersi adalah data meteorologi yang diperoleh dari stasiun cuaca, dan emisi polusi sedangkan output akan menjadi konsentrasi polutan yang sama 
di titik tertentu dari objek simulasi. Model dispersi udara adalah serangkaian persamaan matematika yang menggambarkan perilaku gas/partikel yang dipancarkan ke udara dan digunakan untuk menghitung konsentrasi polutan pada berbagai titik di sekitar sumber emisi (Lokeshwari, 2011).

Model Gaussian Plume adalah sebuah pendekatan yang digunakan untuk mempelajari polutan di udara kerena adanya turbulen difusi dan adveksi yang disebabkan oleh angin (Stockie, et al 2011). Penggunaan Model Polusi Udara Gaussian membutuhkan estimasi dispersi pada arah horizontal dan vertikal untuk memprediksi konsentrasi polutan udara dan dispersi arah horizontal dan vertikal pada umumnya dinyatakan dalam bentuk tetapan $\sigma_{\mathrm{y}}$ dan $\sigma_{\mathrm{z}}$ menyatakan standar deviasi dari distribusi gauss dalam arah horizontal dan vertical (Apiratikul, 2015). Salah satu faktor utama yang mempengaruhi dispersi polutan adalah kecenderungan polutan-polutan untuk berdifusi. Jika suatu sistem memiliki konsentrasi tinggi pada satu tempat dan berpindah ke konsentrasi yang lebih rendah disebut difusi (Holzbecher, 2012). Hal ini ditandai dengan perilaku polutan sepanjang arah yang dipilih memiliki distribusi gaussian. Selain itu kurva konsentrasi polutan terhadap lokasi dari sumber polutan yang berdifusi berbentuk lonceng yang serupa dengan kurva distribusi Gaussian. Dimana konsentrasi maksimum berada di dekat sumber polutan dan konsentrasi semakin berkurang untuk lokasi yang semakin menjauh dari sumber.

Distribusi normal atau distribusi gauss juga disebut sebagai gaussian plume pada kasus steady state dan gaussian puff pada kasus transient. Penggunaan model gauss untuk menghitung konsentrasi polutan akibat emisi sumber titik didasarkan pada pertimbangan yang salah satunya adalah model asap gauss hanya membutuhkan data meterologi angin yaitu arah dan kecepatan dicerobong saja. Dalam sistem tiga dimensi seperti pada gambar dibawah, menunjukkan bahwa terdapat cerobong pada titik pusat, dengan jarak jatuhnya dinyatakan dengan $x$, melebarnya asap dinyatakan dengan $y$, dan tinggi semburan asap dinyatakan dengan $z$.



Gambar 1. Skema Dispersi Gauss

\section{METODE PENELITIAN}

Model Dispersi Gauss

Dispersi Gauss adalah model yang biasa digunakan untuk memodelkan proses sebaran dari penyebaran polusi udara yang berasal dari cerobong asap pabrik. Model matematika secara intensif digunakan dalam ilmu lingkungan untuk berbagai alasan status penilaian, statistik, pemodelan, peramalan, perencanaan, dan analisis skenario (Steinberga et al. 2018). Model dispersi Gauss sering digunakan untuk memprediksi dispersi polutan secara kontinyu yang dari permukaan atau dataran tinggi. Hal ini mengasumsikan bahwa dispersi polutan memiliki distribusi probabilitas normal. Analisis sebaran konsentrasi polutan dilakukan dengan menggunakan dispersi Gauss yang persamaannya adalah sebagai berikut.

$$
\begin{aligned}
& c(x, y, z)=\frac{Q}{2 \pi \sqrt{2 D_{y} x} \sqrt{2 D_{z} x}} \exp \\
& \left.\left(-\frac{1}{2} v\left(\frac{y}{\sqrt{2 D_{y} x}}\right)^{2}\left[\left(\frac{z-H}{\sqrt{2 D_{z} x}}\right)^{2}+\right]\left(\frac{z+H}{\sqrt{2 D_{z} x}}\right)^{2}\right]\right)
\end{aligned}
$$




$$
\begin{aligned}
& c(x, y, z)=\frac{Q}{2 \pi \sqrt{4 x^{2} D_{y} D_{z}}} \\
& \exp \left(-\frac{v}{2 x}\left[\left(\frac{y^{2}}{2 D_{y}}\right)\left[\begin{array}{l}
\left(\frac{(z-H)^{2}}{2 D_{z}}\right) \\
\left(\frac{(z+H)^{2}}{2 D_{z}}\right)
\end{array}\right]\right)\left(\frac{\lambda}{v} x\right)\right)
\end{aligned}
$$

$$
\begin{aligned}
& c(x, y, z)=\frac{Q}{4 \pi x \sqrt{D_{y} D_{z}}} \exp \left(-\frac{v y^{2}}{4 x D_{y}}\right) \\
& {\left[\begin{array}{l}
\exp \left(-\frac{v(z-H)^{2}}{4 x D_{z}}\right)+ \\
\exp \left(-\frac{v(z+H)^{2}}{4 x D_{z}}\right)
\end{array}\right] \exp \left(\frac{\lambda}{v} x\right)}
\end{aligned}
$$

Karena pemodelan dispersi Gauss ini dilakukan pada level konsentrasi pada permukaan tanah (Ground Level Concentration) dengan nilai $\mathrm{z}=0$, sehingga persamaannya menjadi:

$$
\begin{aligned}
& c(x, y, z)=\frac{Q}{4 \pi x \sqrt{D_{y} D_{z}}} \\
& \exp \left(-\frac{v}{4 x}\right)\left(\frac{y^{2}}{D_{y}}+\frac{H^{2}}{D_{z}}\right) \exp \left(\frac{\lambda}{v} x\right)
\end{aligned}
$$

Keterangan: $c(x, y, z)=$ konsentrasi polutan pada titik $x, y, z\left(\mathrm{~g} / \mathrm{m}^{3}\right), Q=$ laju emisi polutan $(\mathrm{g} / \mathrm{s}), v=$ kecepatan angin rata-rata pada tinggi cerobong $(\mathrm{m} / \mathrm{s}), \quad \sigma_{\mathrm{y}}=$ tetapan dispersi secara horizontal terhadap sumbu $x$ (m), $\sigma_{\mathrm{z}}=$ tetapan dispersi secara vertikal terhadap sumbu $x(\mathrm{~m}), x=$ jarak jatuhnya polutan $(\mathrm{m}), \quad y=$ jarak pengamatan sejajar dengan sumbu $x(\mathrm{~m}), z=$ jarak pengamatan tegak lurus dengan sumbu $y(\mathrm{~m}), H=$ tinggi efektif emisi (m), Dengan menggunakan persamaan (4) disamping tersebut, akan diformulasikan dengan menggunakan bahasa pemograman matlab untuk mendapatkan gambaran hasil sebaran konsentrasi polutan yang memiliki beberapa asumsi yang digunakan diantaranya:

1. Emisi polutan yang keluar dari cerobong asap kontiniu dan konstan.

2. Permukaan sebaran polutan relatif datar.

3. Kecepatan angin konstan dalam waktu dan kemiringan.

4. Pada arah angin utama, adveksi mendominasi dari difusi.

5. Ketika polutan menyentuh tanah tidak diserap.

6. Reaksi yang melibatkan senyawa pencemar di udara diabaikan.

7. Kondisi pencemar steady state, atau tidak akan berubah terhadap waktu.

\section{HASIL DAN PEMBAHASAN}

Pada penelitian ini penyebaran konsentrasi pada level permukaan tanah (Ground Level Concentration) dan dilakukan dengan memvariasiakan tinggi efektif emisi $(\mathrm{H})$. Adapun jenis dari bahan bakar yang digunakan cerobong pabrik adalah bahan bakar jenis solar yang menghasilkan polutan sulfur dioksida $\left(\mathrm{SO}_{2}\right)$. Untuk data polutan $\mathrm{SO}_{2}$ diadopsi dari data penelitian dilakukan oleh Yayat Ruhiat (Ruhiat, et al 2008). Selanjutnya akan dilakukan perbandingan penyebaran konsentrasi antara $(H=30 \mathrm{~m}, 40 \mathrm{~m}$, dan $50 \mathrm{~m}$ pada $\mathrm{v}=2 \mathrm{~m} / \mathrm{s})$ dengan $(H=30 \mathrm{~m}, 40 \mathrm{~m}$, dan $50 \mathrm{~m}$ pada $\mathrm{v}=3 \mathrm{~m} / \mathrm{s}$ ).

\section{A. Hasil Penelitian}

\section{Penyebaran Konsentrasi $\mathrm{SO}_{2}$ dengan kecepatan angin $2 \mathrm{~m} / \mathrm{s}$}

1. Hasil penyebaran konsentrasi polutan untuk $H=30 \mathrm{~m}$

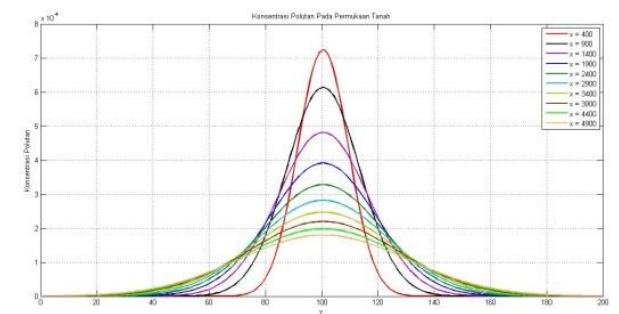


(a)

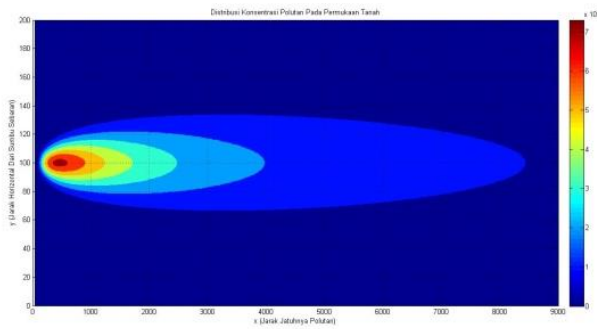

(b)

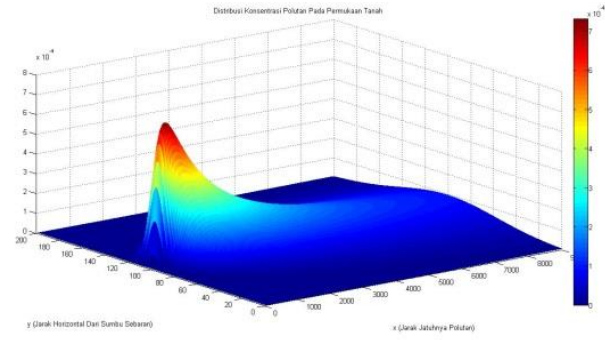

(c)

Gambar 2. Penyebaran konsentarsi polutan untuk $H=30 \mathrm{~m}$, (a) grafik, (b) $2 D$, (c) $3 D$

2. Hasil penyebaran konsentrasi polutan untuk $H=40 \mathrm{~m}$

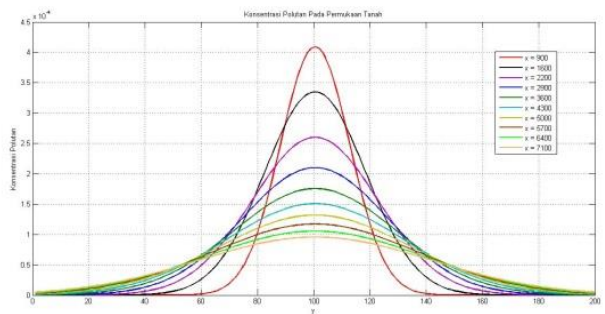

(a)



(b)

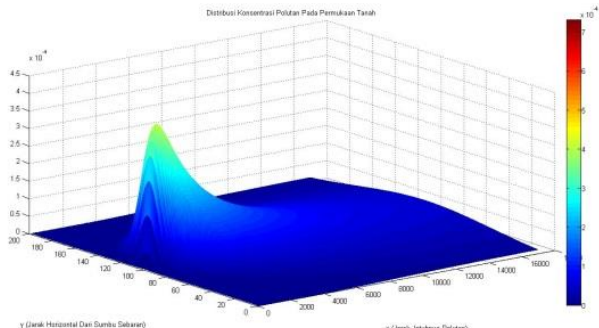

(c)

Gambar 3. Penyebaran konsentarsi polutan untuk $H=40 \mathrm{~m}$, (a) grafik, (b) $2 D$, (c) $3 D$
3. Hasil penyebaran konsentrasi polutan untuk $H=50 \mathrm{~m}$

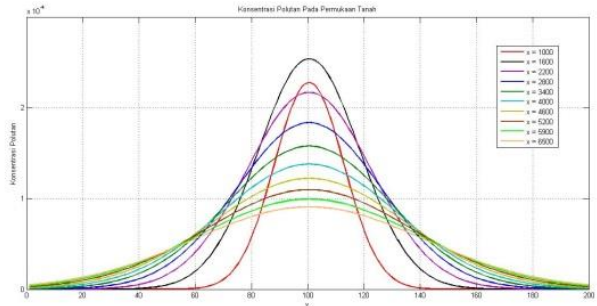

(a)



(b)

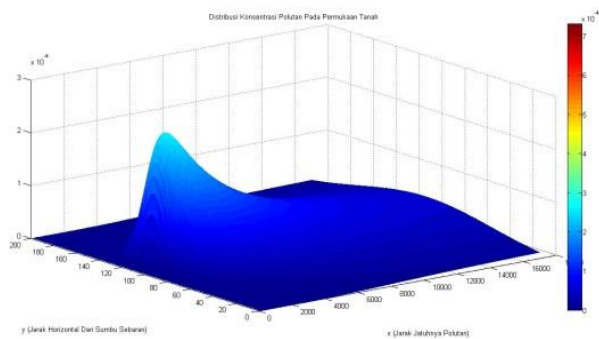

(c)

Gambar 4. Penyebaran konsentarsi polutan untuk $H=50 \mathrm{~m}$, (a) grafik, (b) $2 D$, (c) $3 D$

\section{Penyebaran Konsentrasi $\mathrm{SO}_{2}$ dengan kecepatan angin $3 \mathrm{~m} / \mathrm{s}$}

1. Hasil penyebaran konsentrasi polutan untuk $H=30 \mathrm{~m}$



(a)

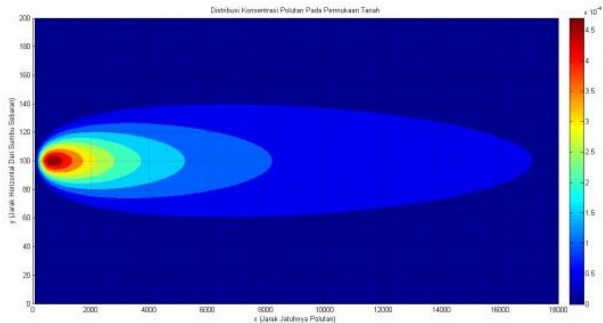

(b) 


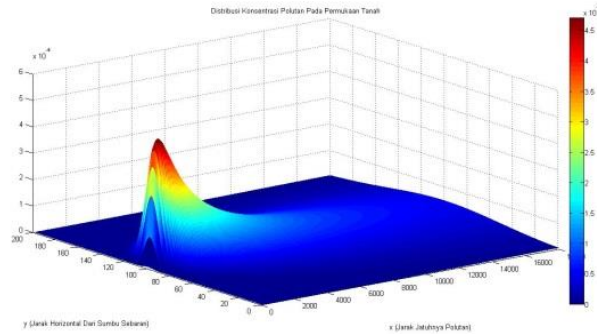

(c)

Gambar 5. Penyebaran konsentarsi polutan untuk $H=30 \mathrm{~m}$, (a) grafik, (b) $2 D$, (c) $3 D$

2. Hasil penyebaran konsentrasi polutan untuk $H=40 \mathrm{~m}$

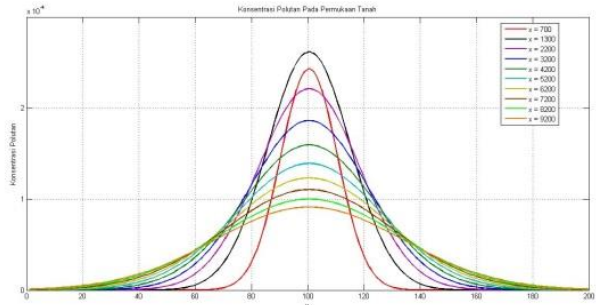

(a)

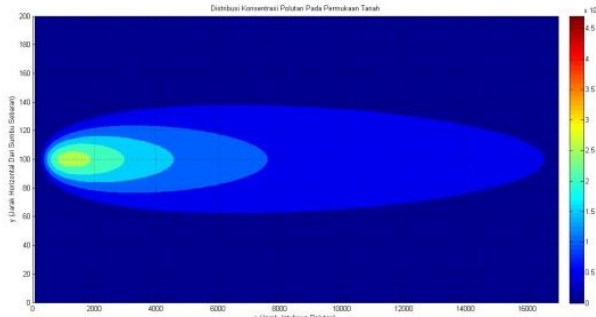

(b)

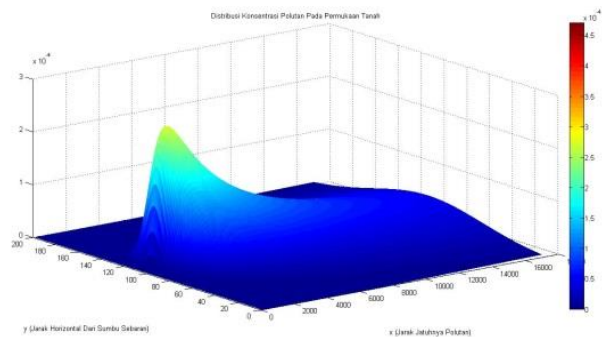

(c)

Gambar 6. Penyebaran konsentarsi polutan untuk $H=40 \mathrm{~m}$, (a) grafik, (b) $2 D$, (c) $3 D$

3. Hasil penyebaran konsentrasi polutan untuk $H=50 \mathrm{~m}$

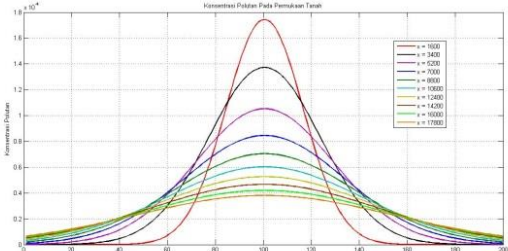

(a)

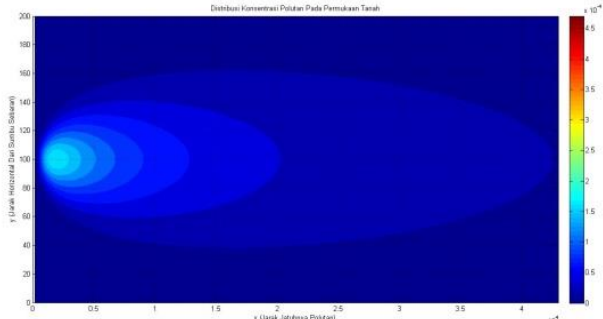

(b)

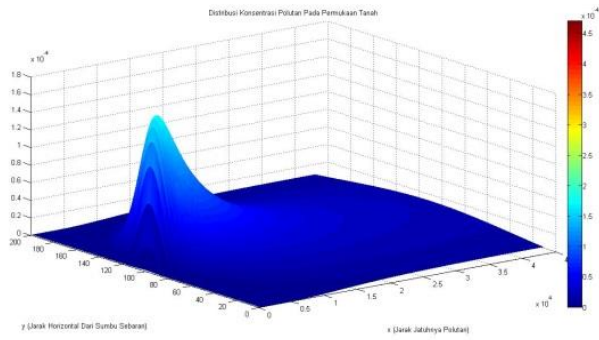

(c)

Gambar 7. Penyebaran konsentarsi polutan untuk $H=50 \mathrm{~m}$, (a) grafik, (b) $2 D$, (c) $3 D$

\section{B. Pembahasan}

Dari gambar hasil diatas dapat menjelaskan proses penyebaran dari konsentrasi polutan $\mathrm{SO}_{2}$ di udara. Dimana dengan memvariasikan tinggi efektif emisi $(H)$ dan kecepatan anginnya, dimana dengan $H=30 \mathrm{~m}, 40 \mathrm{~m}, 50 \mathrm{~m}$, dan untuk kecepatan anginnya $v=2 \mathrm{~m} / \mathrm{s}$ dan $3 \mathrm{~m} / \mathrm{s}$ didapatkan hasil yang berbeda. Semakin tinggi nilai $H$ maka konsentrasi polutan akan semakin jauh tersebar dengan konsentrasi yang mengecil seiring dari jarak sebarannya. Sehingga dapat disimpulkan perbandingan penyebaran konsentrasi $\mathrm{SO}_{2}$ dengan kecepatan angin $2 \mathrm{~m} / \mathrm{s}$ pada $H=30 \mathrm{~m}, 40 \mathrm{~m}$, dan $50 \mathrm{~m}$ dengan penyebaran konsentrasi $\mathrm{SO}_{2}$ dengan kecepatan angin $3 \mathrm{~m} / \mathrm{s}$ pada $H=$ $30 \mathrm{~m}, \quad 40 \mathrm{~m}$, dan $50 \mathrm{~m}$ sama-sama mengakibatkan konsentrasi polutan semakin mengecil dan semakin jauh jarak jangkauannya jika $H$ semakin membesar. Pengaruh angin juga sangat berpengaruh, hal ini dapat dilihat hasil dari $H=30 \mathrm{~m} v=2 \mathrm{~m} / \mathrm{s}$ daerah yang memiliki konsentrasi tertingi pada jarak $\pm 650 \mathrm{~m}$ dan jarak jangkauan sebaran konsentrasi polutan pada $\pm 8400 \mathrm{~m}$, sedangkan untuk hasil dari $H=30 \mathrm{~m} v=3$ $\mathrm{m} / \mathrm{s}$ daerah yang memiliki konsentrasi 
tertingi pada jarak $\pm 750 \mathrm{~m}$ dan jarak jangkauan sebaran konsentrasi polutan pada $\pm 5500 \mathrm{~m}$, semakin besar kecepatan angina tentunya akan mengakibatkan jarak yang semakin jauh. Hal ini sangat dianjurkan dalam pembuatan cerobong asap pabrik dibuat sangat tinggi untuk menanggulangi bahaya dari penyebaran polutan.

\section{PENUTUP}

Kesimpulan yang dapat diambil dalam penelitian ini adalah variasi dari tinggi efektif emisi $(H)$ sangat berpengaruh terhadap sebaran konsentrasi polutan. Jika $H$ diperkecil akan didapatkan hasil sebaran konsentrasi yang lebih besar dan jaraknya jangkauannya semakin dekat. Sebaliknya jika $H$ diper besar maka nilai konsentrasi polutan akan semakin kecil dan jarak jangkauannya akan semakin jauh. Selanjutnya pengaruh dari kecepatan angin $(v)$ juga akan sangat berpengaruh, dimana $v=3 \mathrm{~m} / \mathrm{s}$ dibandingkan $v=2 \mathrm{~m} / \mathrm{s}$ akan mengakibatkan perbedaan nilai dari konsentrasi polutan dan jarak jangkauannya berbeda. Sehingga dari hasil penelitian dapaat disimpulkan dalam pembuatan tinggi cerobong pabrik sangat dianjurkan dibuat tinggi.

\section{REFERENSI}

Apiratikul, R. 2015. Approximation Formula For The Prediction Of Downwind Distance That Found The Maximum Ground Level Concentration Of Air Pollution Based On The Gaussian Model, Procedia - Social and Behavioral Sciences 197, 1257 - 1262.

Brusca, S., Lanzafame, R., Mauro, S. 2016. Theoretical and experimental study of Gaussian Plume model in small scale system, Energy Procedia 101, $58-65$.

Holzbecher, E. 2012. Enviromental Modeling Using Matlab, Springer: London.
Iodice, P., \& Senatore, A. 2015. Air Pollution And Air Quality State In An Italian National Interest Priority Site. Part 2: The Pollutant Dispersion, Energy Procedia 81, 637 $-643$.

Lokeshwari, N., Srinikethan, G., and Hegdec, V.S. 2011. Modelling of Pollutants from a Point Source: A Case study from Coke, International Journal of Current Engineering and Technology, ISSN 2277-4106.

Patmasari, S. 2018. Model Matematika Dari Penyebaran Polutan Di Udara Dengan Model Gaussian Plume, MATHunesa Jurnal Ilmiah Matematika, 6(2), ISSN 2301-911.

Steinberga, I., Sustere, L., Bikse, J., Jr, J.B., Kleferis, J. 2019. Taffic Induced air pollution Modeling: Scenario Analysis for Air Quality Management In Street Canyon, Procedia Computer Science 149 ,384-389.

Stockie, J.M. 2011. The Mathematics of Atmospheric Dispersion Modeling, SIAM Review. 53(2), pp. 349-372.

Varma, S.A.K., Srimurali, M., Varma, S.V.K. 2014. Prediction of Ground Level Concentrations of Air Pollutants Using Gaussian Model, Rayalaseema Thermal Power Project, Kadapa, A.P., India, Energy and Environmental Engineering 2(4), 91-97, DOI: 10.13189/eee.2014.020402.

Xi, X., Li, H., Wallin, F., Avelin,A., Yang, X. 2019. Air Pollution Related Externality of District Heating - A Case Study of Changping, Beijing, Energy Procedia. 4323-4330.

Yayat, R. 2008. Penyebaran Pencemaran Udara Di Kawasan Industri Cilegon. Jurnal Agromet Indonesia. 